\title{
REGIONAL CORRELATION AND CYCLOSTRATIGRAPHY IN THE MID-CRETACEOUS FORMATIONS OF THE IONIAN ZONE
}

\author{
Karakitsios V. ${ }^{1}$, and Agiadi-Katsiaouni K. ${ }^{1}$ \\ ${ }^{1}$ National and Kapodistrian University of Athens, Faculty of Geology and Geoenvironment, \\ Department of Hist.Geology - Paleontology,vkarak@geol.uoa.gr,kagiadi@geol.uoa.gr
}

\begin{abstract}
The mid-Cretaceous period is characterized by the widespread deposition of organic carbon-rich horizons, documenting oceanic anoxic events (OAEs), which correspond to episodes of major disturbances in the carbon cycle. The causes of these events are still widely debated. In this study, the role of orbital variations in the deposition of black shales in the Ionian Zone (Western Greece), an area already known for documenting OAEs is examined. Cyclostratigraphic data for the Lower Aptian interval are interpreted in a climate change context, and specific mechanisms for the deposition of organic carbon-rich horizons are hypothesized. Field observations, stable isotope and total organic carbon analyses, as well as biostratigraphic data enable a correlation between the Gotzikas section and the Paliambella section, also in the Ionian Zone (Epirus, Greece). In addition, Gotzikas section is also correlated with the Poggio le Guaine - Fiume Bosso composite sequence of the Umbria - Marche region (Italy). Lower Aptian sedimentation in the Ionian Basin seems to be controlled by orbital forcing. The short eccentricity and obliquity rhythms are most prominently recorded. Whilst the presence of amplitude modulation cycles indicates towards a lesser control by the long eccentricity and precession periodicities.
\end{abstract}

Key words: Oceanic Anoxic Events, black shales, palaeoclimatology, spectral analysis, orbital forcing.

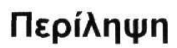

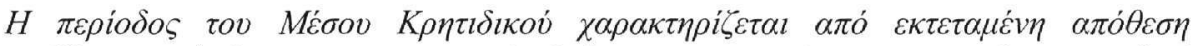

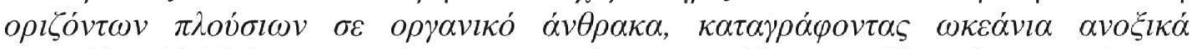

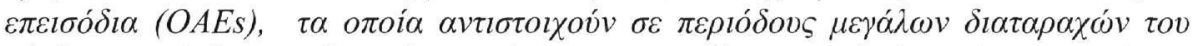

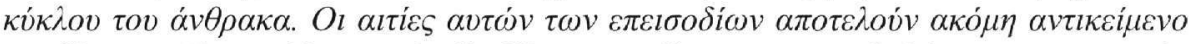

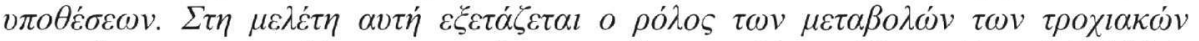

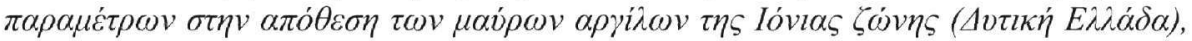

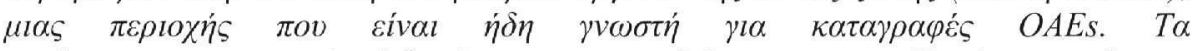

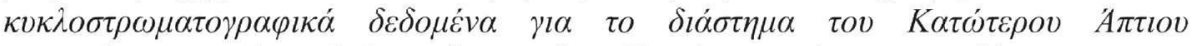

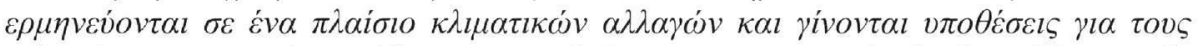

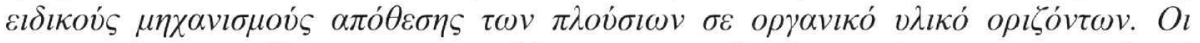

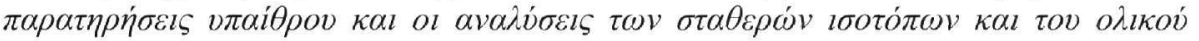

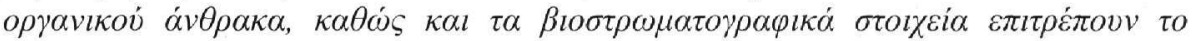

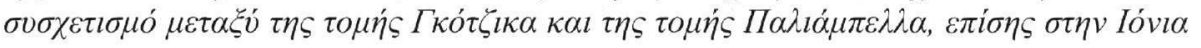




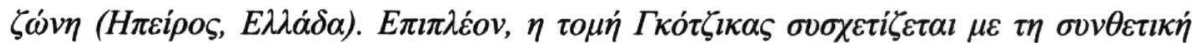

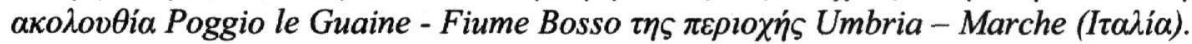

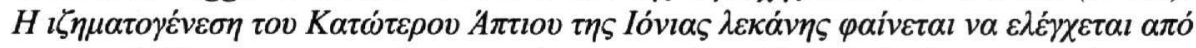

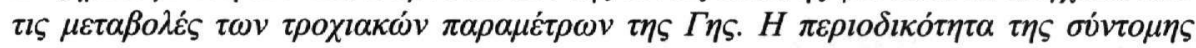

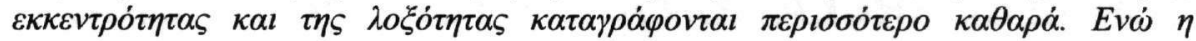

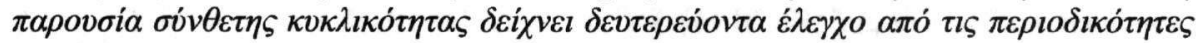

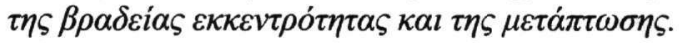

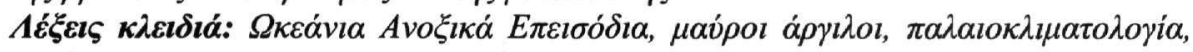

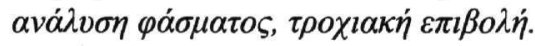

\section{Introduction}

The mid-Cretaceous period is characterized by the widespread deposition of organic carbon-rich horizons, documenting oceanic anoxic events (OAEs), which correspond to episodes of major disturbances in the carbon cycle (Jenkyns 1980). The causes of these events are still widely debated. According to the preservation model, decreased ventilation of the sea floor, due to increased detrital input, led to enhanced carbon burial, as a result of low organic matter remineralisation (Tyson 1995). Alternatively, very high primary productivity levels and overwhelming oxic remineralisation of organic matter, may have been the cause of anoxic conditions on the sea floor, through expansion of the oxygen minimum zone (Parrish 1995). Though both resulting in enhanced preservation of organic matter, it appears that the midCretaceous black shales can be separated in two classes, having an either detrital (D-OAEs) or productivity driven origin (P-OAEs) (Erbacher et al. 1996).

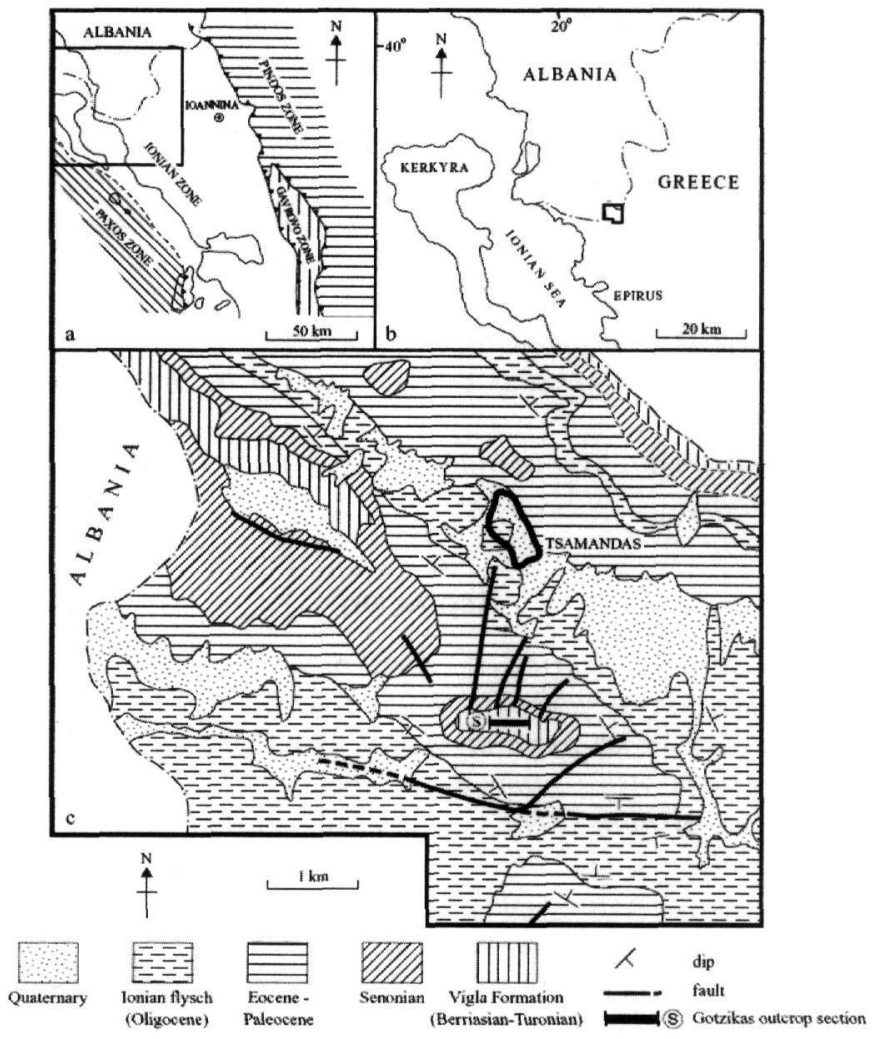

Figure 1 - (a) The zones of NW Hellenides; (b) location of the study area; (c) simplified geological map of the study area (Tsikos et al. 2004b) 
Recent integrated studies of the mid-Cretaceous basin deposits in the Umbria - Marche region in Italy (Galeotti et al. 2003) have confirmed an orbital control on the deposition of bedded cycles and organic carbon-rich facies in this basin. According to these authors, climatic changes, modulated by the orbital forcing, induced changes in the hydrological and atmospheric cycles, led to in enhanced fluxes and preservation of continental-derived organic matter in the black shale horizons.

In this study, the well known Gotzikas section, documenting OAE1b and OAE2 (Tsikos et al. 2004, Karakitsios et al. 2007) is correlated with the Paliambela section, also in the Ionian zone of Western Greece, and the Poggio le Guaire - Fiume Bosso composite sequence of the Umbria Marche region (Italy). In addition, the role of orbital variations in the deposition of black shales in the Ionian Zone (Western Greece) is examined. Furthermore, cyclostratigraphic data are interpreted in a climate change context, and specific mechanisms for the deposition of organic carbon-rich horizons are being hypothesized.

\section{The Study Section}

\subsection{Geological Setting}

During the Early Jurassic, the Ionian Zone was an area of platform carbonate sediment deposition (Pantokrator limestones) on a base comprising primarily of Triassic evaporites. A period of extensional stress associated with the opening of the Neotethys, from the Pliensbachian to the Tithonian, led to a differentiation of the Ionian realm into discrete palaeogeographic "units recording early regional subsidence (Karakitsios 1992). The Lower Cretaceous (Berriasian Turonian) pelagic Vigla Limestone Formation represents the post-rift formation. This sequence is defined by a Lower Berriasian unconformity at the base of the Vigla Limestone Formation, which largely obscures pre-existing syn-rift structures. Minor off- and on-lap movements along the Ionian Basin margin continued until the Late Eocene, when flysch sedimentation commenced. The evolution of the Ionian Basin constitutes a good example of inversion tectonics in a basin with an evaporitic base (Karakitsios 1995).

The Vigla Limestone Formation s.l. comprise a thick succession of thin-layered $(5-10 \mathrm{~cm})$, sublithographic pelagic limestones with radiolaria, which are rhythmically interbedded with centimetre- to decimetre-thick radiolarian chert beds. The upper part also contains of a series of intercalated organic carbon-rich marlstones and shales, termed the Vigla Shale Member (Karakitsios 1995, Rigakis and Karakitsios 1998). According to a previous examination of the Gotzikas section, south of the village Tsamandas (NW Epirus; Fig.1) has shown that the Vigla Limestone Formation s.l. has an approximate $100 \mathrm{~m}$ thickness (Tsikos et al. 2004b). The upper $80 \mathrm{~m}$ of this consist of a rhythmically alternating, thinly bedded limestone/black chert succession (Vigla limestones s.s.). Towards the lower $15-20 \mathrm{~m}$ of this interval, the limestones become more massive, pinkish-grey in colour and increasingly silicified. Within this portion, Tsikos et al. (2004b) have identified an isolated black shale horizon ( $15 \mathrm{~cm}$ thickness), as corresponding to the "Paquier event" (OAE1b). These silicified Vigla limestones continue stratigraphically lower for another $8-10 \mathrm{~m}$ below this black shale (Fig. 2). The sediments then pass downwards to the Vigla Shale Member.

According to Tsikos et al. (2004b), the Vigla Shale Member, in Gotzikas section, spans the Aptian - Lower Albian interval. However the upper portion of this is not visible in the field. In the lowermost 13,22 $\mathrm{m}$ of the succession, 20 individual organic carbon rich marly horizons are seen, ranging in thickness from 10 to $40 \mathrm{~cm}$ (Fig.2). These layers are dark grey to black, well laminated and free of any evidence of bioturbation. They are interbedded with reddish-grey, $20-50 \mathrm{~cm}$ thick marly limestone beds, silicified in places and containing common intercalations of dark chert layers $(5-10 \mathrm{~cm}$ thick$)$. 


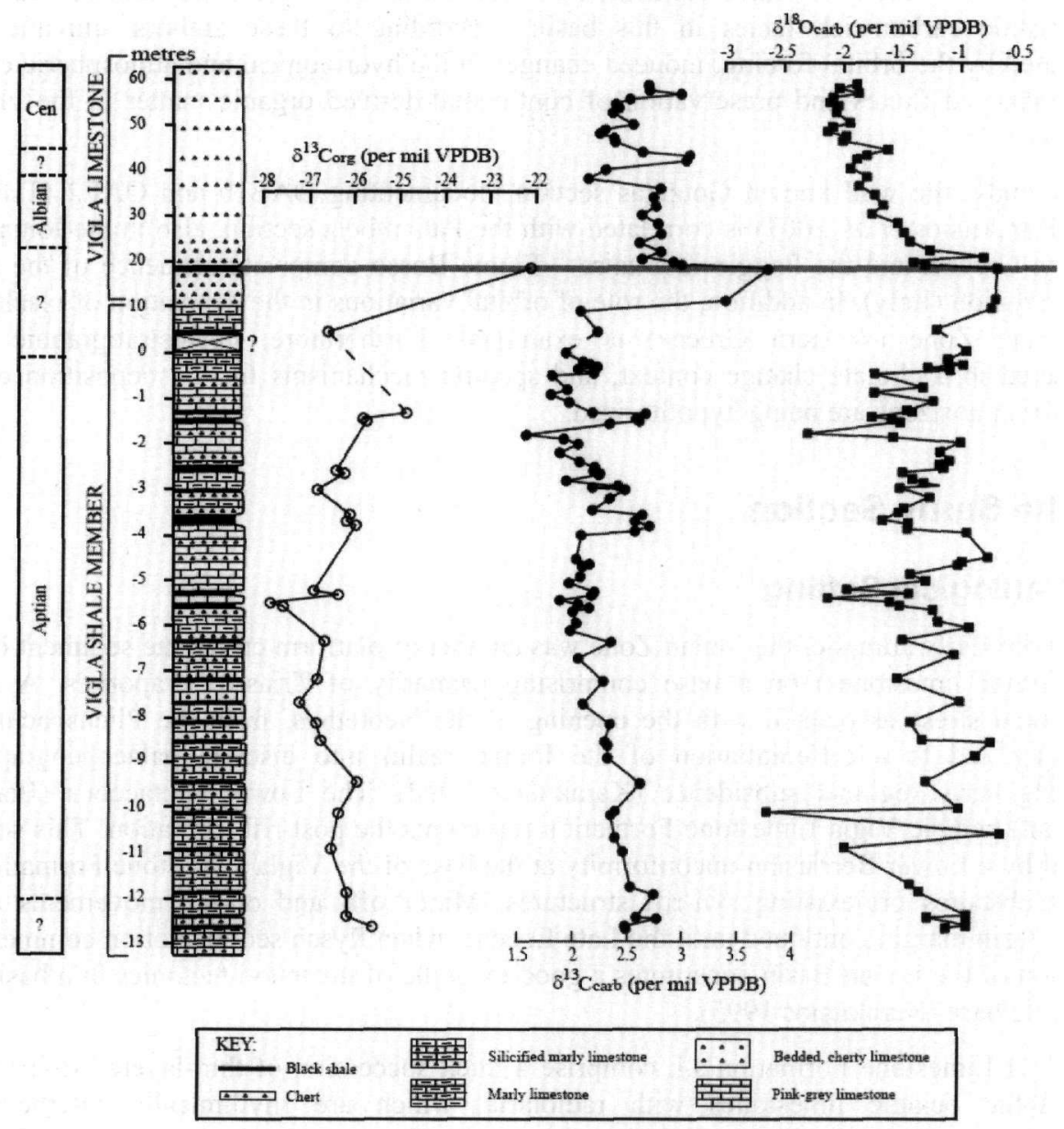

Figure 2 - Lithostratigraphic log and bulk stable $(\mathrm{C}, \mathrm{O})$ isotope profiles through the Vigla section in the Gotzikas area (Tsikos et al. 2004). The highlighted level corresponds to the 'Paquier' level (OAE1b)

The stratigraphically higher parts of the Vigla Limestone Formation s.l., in this section, lack organic carbon-rich sediments, except for an isolated black shale horizon, about $40 \mathrm{~m}$ above the "Paquier" level. This horizon is $\sim 35 \mathrm{~cm}$ thick comprising of two distinct, finely laminated subunits separated by a thin, cherty layer. This horizon has been shown to correspond to the Cenomanian - Turonian "Bonarelli" event (OAE2) (Karakitsios et al. 2007).

\subsection{Biostratigraphy}

Biostratigraphic analyses of planktonic foraminifera and calcareous nannofossils (Tsikos et al. 2004b, Karakitsios et al. 2007) suggest that the Vigla limestones s.s. in the Gotzikas section span the Albian - Turonian interval. The lowermost $13.22 \mathrm{~m}$ of the section comprising of the Vigla Shale Member (i.e. 26.8-14.9m below the OAE1b) may be assigned to the Lower Aptian, based on the presence of the nannofossils Assipetra infracretacea larsonii, Hayesites irregularis, and Rucinolithus terebrasletnarius youngii, as well as the absence of Upper Aptian species (Tsikos et al. 2004b). 


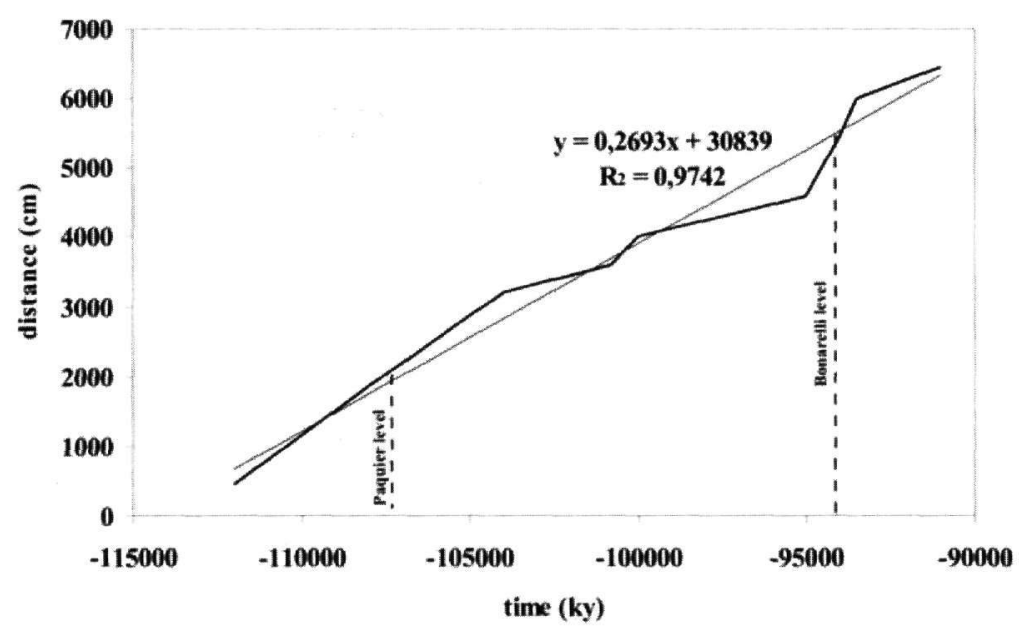

Figure 3 - Age model for the upper part of the Vigla limestones in Gotzikas section. The mean sedimentation rate is $0.2693 \mathrm{~cm} / \mathrm{ky}$. The trend line was obtained using a linear fit

The black shale corresponding to the "Paquier" event in the lower portion of the section marks the Lower to Middle Albian, as shown by the presence of the calcareous nannofossil Hayesites albiensis $3 \mathrm{~m}$ below to $10 \mathrm{~m}$ above this horizon. The $\sim 20 \mathrm{~m}$-thick interval above the OAE1b level is assigned to the Middle to Upper Albian period. This is suggested by the first occurrence of the calcareous nannofossil Quadrum eneabrachium, and the presence of the planktonic foraminifer Biticinella breggiensis, followed by the presence of the planktonic foraminifera Rotalipora appeninica and Planomalina buxtorfi, and the nannofossil Eiffellithus turriseiffelii (Premoli Silva and Sliter, 1995, Karakitsios et al. 2007).

A Middle Cenomanian age is given to the $6 \mathrm{~m}$ of sediments overlying the Upper Albian interval due to the first occurrence of Rotalipora cushmani and the continued presence of $R$. appenninica. Also Praeglobotruncana gibba occurs $4.5 \mathrm{~m}$ higher in the succession. These datum have been used to correlate this black-shale unit with the Cenomanian - Turonian boundary "Bonarelli" level of the Umbria-Marche region (Tsikos et al. 2004a, Karakitsios et al. 2007). Finally the first occurrence of Marginotruncana gr. pseudolinneiana constrains the uppermost part of the succession as Turonian in age (Premoli Silva and Sliter 1995).

\subsection{Sedimentation rate}

An age model (Fig.3) was contructed, based on the first and last occurrences shown in Table 2, with reference to the biostratigraphic scheme by Bralower et al. (1995) and the Geologic Time Scale 2004 (Gradstein et al. 2004). The mean sedimentation rate for the upper part of the Vigla limestones s.s. (Albian - Turonian), in Gotzikas section, can be approximated at $0.27 \mathrm{~cm} / \mathrm{ky}$ $\left(\mathrm{R}^{2}=0.97\right)$. Also, there appears to be a substantial relative increase in the sedimentation rate, to $1.10 \mathrm{~cm} / \mathrm{ky}$, about $5.5 \mathrm{~m} \quad(500 \mathrm{ky})$ prior to the "Bonarelli event". Accumulation of sediment returns to a lower rate $(0.30 \mathrm{~cm} / \mathrm{ky})$ after this event horizon. Mean sedimentation rate, for the lower part of the Vigla Shale Member in this section, is $0.66 \mathrm{~cm} / \mathrm{ky}$.

\subsection{Stable isotope and TOC data}

The complete stable isotope and TOC data, across the Vigla Limestone Formation in the Gotzikas section (Table 1, 2) are thoroughly described elsewhere (Tsikos et al. 2004a, 2004b, Karakitsios et al. 2007). Samples 1-7 and 9-42 (Table 1) exhibit TOC (wt \%) values between 1-2\%. 
Table 1 - Complete dataset for the upper part of the Vigla formation (Albian - Turonian), in Gotzikas section

\begin{tabular}{|c|c|c|c|c|c|c|c|}
\hline sample & $\begin{array}{c}\text { TOC } \\
(w t \%)\end{array}$ & $\begin{array}{c}\mathrm{CaCO}_{3} \\
(w \mathrm{wt} \%)\end{array}$ & $\begin{array}{c}\delta^{13} C_{\text {TOC }} \\
(\%)\end{array}$ & $\begin{array}{l}\delta^{13} \mathbf{C} \\
(\%) \\
\end{array}$ & $\begin{array}{l}\delta^{18} O \\
(\% 0)\end{array}$ & $\begin{array}{c}\text { height } \\
\text { (m) }\end{array}$ & $\overline{\text { event }}$ \\
\hline 1 & & & & 2.64 & -1.50 & 83.00 & $\begin{array}{l}\text { LO Marginotruncana gr. } \\
\text { pseudolinneiana }\end{array}$ \\
\hline 2 & & & & 2.75 & -1.59 & 77.00 & \\
\hline 3 & & & & 2.73 & -1.44 & 74.50 & \\
\hline 4 & & & & 3.00 & -1.90 & 72.00 & \\
\hline 5 & & & & 2.91 & -1.93 & 70.00 & \\
\hline 6 & & & & 3.02 & -2.14 & 64.50 & LO Praeglobotruncana gibba \\
\hline 7 & & & & 2.52 & -1.77 & 62.00 & $\begin{array}{c}\text { FO Marginotruncana gr. } \\
\text { pseudolinneiana }\end{array}$ \\
\hline 8 & 44.5 & & -22.21 & & & 60.00 & "Bonarelli event" (OAE2) \\
\hline 9 & & & & 2.60 & -1.83 & 59.00 & FO Praeglobotruncana gibba \\
\hline 10 & & & & 2.70 & -2.04 & 57.50 & \\
\hline 11 & & & & 2.99 & -1.87 & 56.50 & \\
\hline 12 & & & & 2.53 & -2.09 & 55.50 & \\
\hline 13 & & & & 2.40 & -2.11 & 54.50 & $\begin{array}{c}\text { LO R.cushmani, LOR. } \\
\text { appenninica }\end{array}$ \\
\hline 14 & & & & 2.42 & -2.05 & 53.50 & \\
\hline 15 & & & & 2.37 & -2.07 & 52.50 & \\
\hline 16 & & & & 2.31 & -2.05 & 51.00 & \\
\hline 17 & & & & 2.55 & -1.94 & 50.00 & \\
\hline 18 & & & & 2.29 & -2.10 & 49.00 & \\
\hline 19 & & & & 2.25 & -2.14 & 48.00 & \\
\hline 20 & & & & 2.38 & -1.99 & 47.00 & \\
\hline 21 & & & & 2.39 & -2.01 & 46.00 & FO R.cushmani \\
\hline 22 & & & & 2.48 & -1.72 & 45.00 & \\
\hline 23 & & & & 2.64 & -1.63 & 44.00 & \\
\hline 24 & & & & 3.07 & -1.81 & 43.00 & \\
\hline 25 & & & & 3.04 & -1.89 & 42.00 & LO P.buxtorfi \\
\hline 26 & & & & 2.30 & -1.94 & 40.00 & $\begin{array}{c}\text { FO Planomalina buxtorfi, FO } \\
\text { Rotalipora appenninica, FO } \\
\text { Eiffelithus ruttiseiffelii }\end{array}$ \\
\hline 27 & & & & 2.14 & -1.81 & 38.00 & \\
\hline 28 & & & & 2.81 & -1.87 & 36.00 & LO B. breggiensis \\
\hline 29 & & & -25.78 & & & 35.00 & \\
\hline 30 & & & -26.33 & & & 34.50 & \\
\hline 31 & & & & 2.74 & -1.74 & 34.30 & \\
\hline 32 & & & -26.12 & & & 34.00 & \\
\hline 33 & & & & 2.76 & -1.67 & 32.00 & FO Biticinella breggiensis \\
\hline 34 & & & -26.49 & & & 31.00 & \\
\hline 35 & & & & 2.63 & -1.77 & 30.00 & \\
\hline 36 & & & & 2.78 & -1.55 & 29.00 & LO Hayesites albiensis \\
\hline 37 & & & -26.40 & & & 26.50 & \\
\hline
\end{tabular}




\begin{tabular}{|l|l|l|l|l|l|l|l|}
\hline 38 & & & & 2.81 & -1.49 & 25.00 & FO Quadrum eneabrachium \\
\hline 39 & & & & 2.61 & -1.44 & 23.50 & \\
\hline 40 & & & & 2.81 & -1.27 & 22.00 & \\
\hline 41 & & & -26.86 & & & 21.00 & \\
\hline 42 & & & & 2.62 & -0.78 & 20.00 & \\
\hline 43 & 28.87 & 23.25 & -22.14 & 2.92 & -1.32 & 19.00 & "Paquier event" (OAE1b) \\
\hline 44 & & & & 2.97 & -1.42 & 18.50 & \\
\hline 45 & & & & 3.79 & -0.70 & 16.00 & FO Hayesites albiensis \\
\hline 46 & & & & 3.39 & -0.72 & 12.00 & \\
\hline 47 & & & & 2.07 & -0.75 & 9.50 & \\
\hline 48 & 2.33 & 76.67 & -26.61 & 2.23 & -1.21 & 4.50 & \\
\hline
\end{tabular}

Table 2 - Complete dataset for the lower part of Gotzikas section (Lower Aptian)

\begin{tabular}{|c|c|c|c|c|c|c|}
\hline sample & $\begin{array}{c}\text { TOC } \\
\text { (wt\%) }\end{array}$ & $\begin{array}{c}\mathbf{C a C O}_{3} \\
\text { (wt\%) }\end{array}$ & $\begin{array}{c}\mathbf{\delta}^{\mathbf{1 3}} \mathbf{C}_{\text {TOC }} \\
\text { (\%o) }\end{array}$ & $\begin{array}{c}\mathbf{\delta}^{\mathbf{1 3}} \mathbf{C} \\
\mathbf{( \% )}\end{array}$ & $\begin{array}{c}\mathbf{\delta}^{\mathbf{1 8}} \mathbf{O} \\
\mathbf{( \% )}\end{array}$ & $\begin{array}{c}\text { height } \\
\text { (m) }\end{array}$ \\
\hline V1 & & & & 1.94 & -0.96 & -0.10 \\
\hline V2 & & & & 1.88 & -0.98 & -0.20 \\
\hline V3 & & & & 2.10 & -1.12 & -0.30 \\
\hline V4a & & & & 2.16 & -1.12 & -0.36 \\
\hline V4b & & & & 2.23 & -0.99 & -0.42 \\
\hline V4c & & & & 2.05 & -1.28 & -0.48 \\
\hline V4d & & & & 2.19 & -1.11 & -0.54 \\
\hline V4e & & & & 1.81 & -1.75 & -0.60 \\
\hline V7 & & & & 1.95 & -1.34 & -0.90 \\
\hline V8 & & & & 1.80 & -1.75 & -1.02 \\
\hline V9 & & & & 1.97 & -1.24 & -1.20 \\
\hline V11 & & & & 2.18 & -1.46 & -1.40 \\
\hline V12a & 1.58 & 76.58 & -24.86 & 2.67 & -1.43 & -1.43 \\
\hline V12b & & & & 2.35 & -1.83 & -1.52 \\
\hline V12c & 2.08 & 77.92 & -25.84 & 2.58 & -1.77 & -1.55 \\
\hline V13 & 2.50 & 81.17 & -25.75 & 2.61 & -1.60 & -1.60 \\
\hline V14 & & & & 2.34 & -1.52 & -1.65 \\
\hline V16 & & & & 1.57 & -2.31 & -1.90 \\
\hline V18 & & & & 1.92 & -1.59 & -2.00 \\
\hline V19 & & & & 2.05 & -1.01 & -2.10 \\
\hline V20 & & & & 1.88 & -1.18 & -2.30 \\
\hline V21 & & & & 2.06 & -1.11 & -2.50 \\
\hline V22 & & & & 2.20 & -1.19 & -2.60 \\
\hline V23a & 1.41 & 91.33 & -26.43 & 2.19 & -1.16 & -2.67 \\
\hline V23b & 2.34 & 83.96 & -26.25 & 2.24 & -1.50 & -2.75 \\
\hline V24 & & & & 1.94 & -1.42 & -2.90 \\
\hline V25a & & & & 2.41 & -1.33 & -3.00 \\
\hline V25b & & & & 2.18 & -1.19 & -3.05 \\
\hline V26 & 3.35 & 61.67 & -26.83 & 2.48 & -1.53 & -3.10 \\
\hline V27 & & & & 2.34 & -1.27 & -3.30 \\
\hline
\end{tabular}




\begin{tabular}{|c|c|l|l|l|l|l|}
\hline V28 & & & & 2.18 & -1.49 & -3.55 \\
\hline V29a & 2.77 & 74.62 & -26.10 & 2.64 & -1.54 & -3.65 \\
\hline V29b & 2.15 & 84.67 & -26.20 & 2.57 & -1.67 & -3.80 \\
\hline V29c & 2.64 & 81.50 & -25.97 & 2.70 & -1.45 & -3.90 \\
\hline V30 & & & & 2.57 & -1.46 & -4.00 \\
\hline V32 & & & & 2.08 & -0.96 & -4.10 \\
\hline V33 & & & & 2.03 & -0.78 & -4.62 \\
\hline V34a & & & & 2.15 & -1.00 & -4.74 \\
\hline V34b & & & & 2.09 & -1.03 & -4.79 \\
\hline V35a & & & & 2.07 & -1.44 & -4.99 \\
\hline V35b & & & & 1.97 & -1.31 & -5.14 \\
\hline V38 & 1.88 & 79.58 & -26.91 & 2.20 & -1.97 & -5.34 \\
\hline V39 & 1.08 & 74.42 & -26.79 & 2.17 & -1.45 & -5.41 \\
\hline V41a & 2.15 & 75.75 & -27.88 & 2.05 & -1.61 & -5.61 \\
\hline V41b & 3.19 & 72.92 & -27.59 & 2.15 & -1.52 & -5.69 \\
\hline V42 & & & & 2.00 & -1.24 & -5.79 \\
\hline V43a & & & & 2.03 & -1.20 & -6.04 \\
\hline V43b & & & & 1.98 & -0.94 & -6.19 \\
\hline V45 & 2.57 & 54.08 & -26.67 & 2.35 & -1.50 & -6.44 \\
\hline V46 & & & & 2.05 & 1.07 & -6.79 \\
\hline V47 & 4.42 & 67.83 & -26.84 & 2.28 & -1.55 & -7.29 \\
\hline V48 & 1.54 & 83.42 & -27.22 & 2.10 & -1.01 & -7.79 \\
\hline V49 & 2.39 & 80.08 & -26.86 & 2.34 & -1.44 & -8.24 \\
\hline V50 & 3.61 & 53.35 & -26.75 & 2.29 & -1.34 & -8.64 \\
\hline V51 & & & & 2.32 & -0.76 & -8.70 \\
\hline V52 & & & & 2.32 & -0.89 & -9.50 \\
\hline V54 & 2.43 & 81.30 & -25.96 & 2.62 & -1.31 & -10.05 \\
\hline V55 & & & & 2.39 & -1.03 & -10.65 \\
\hline V56 & 1.77 & 20.00 & -26.37 & 2.35 & -2.66 & -10.72 \\
\hline V57 & & & & 2.39 & -0.68 & -11.22 \\
\hline V58 & 0.27 & 41.00 & -26.52 & 2.46 & -2.00 & -11.52 \\
\hline V59 & & & & 2.53 & -1.44 & -12.32 \\
\hline V60 & 2.29 & 84.50 & -26.20 & 2.74 & -1.37 & -12.47 \\
\hline V61 & & & & 2.58 & -0.96 & -12.97 \\
\hline V62 & 6.33 & 59.92 & -26.20 & 2.77 & -1.30 & -12.99 \\
\hline V63 & & & & 2.48 & -0.96 & -13.17 \\
\hline & 2.77 & 81.12 & -25.63 & 2.49 & -1.14 & -13.22 \\
\hline
\end{tabular}

\section{Results}

\subsection{Regional correlation}

The field observation, the stable isotopic and total organic carbon analyses, as well as the biostratigraphic information derived from the samples enabled the correlation between the Gotzikas section and the Paliambella section (Danelian et al. 2004) in the Ionian Zone (Epirus, Greece), and the correlation of the study section and the Poggio le Guaine - Fiume Bosso composite sequence (Galeotti et al. 2003) of the Umbria - Marche region (Italy), an area with 
Gotzikas Section

(Ionian Zone, NW Greece)

Paliambela Section (Ionian Zone, NW Greece)
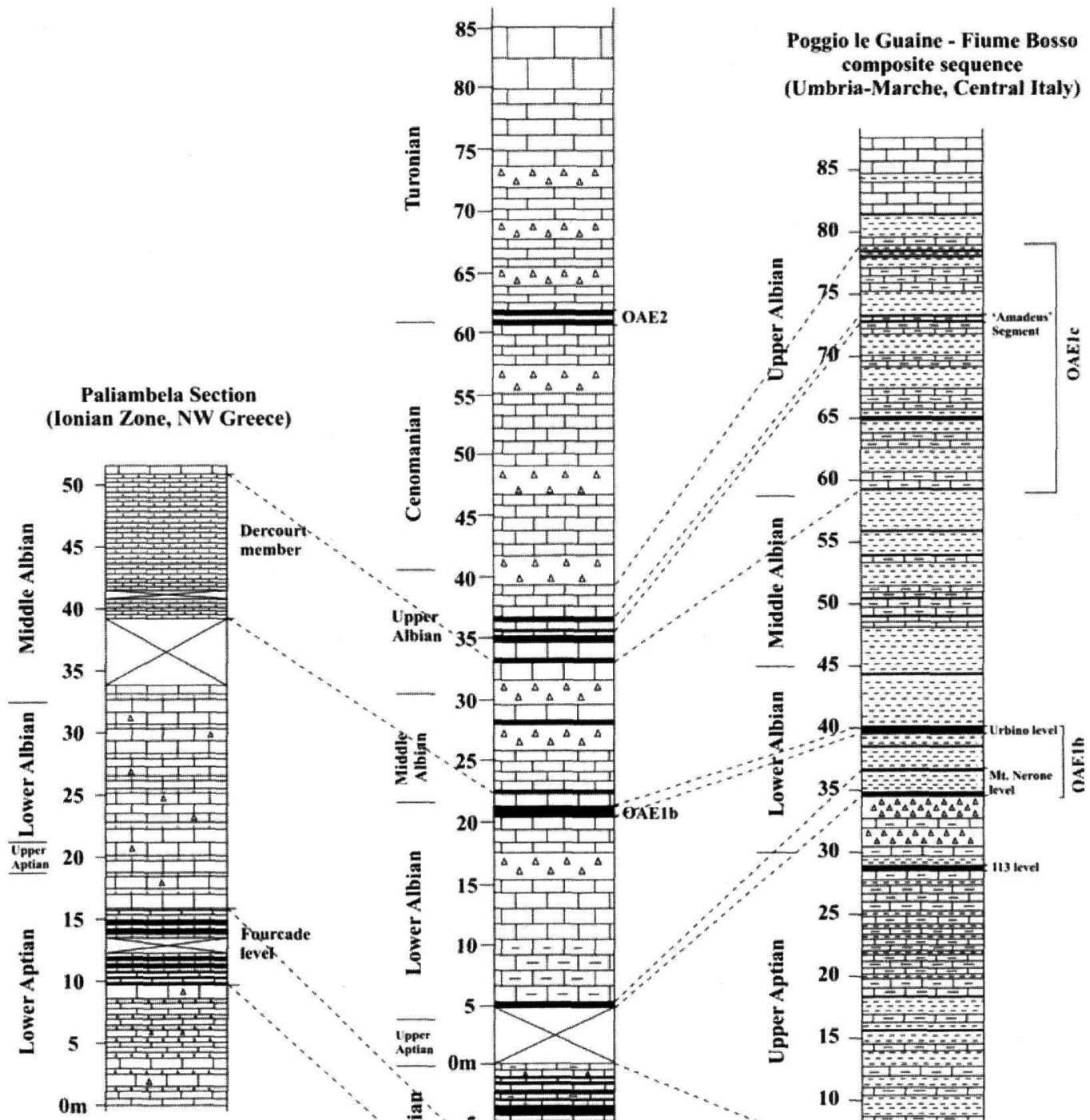
sufficiently comparable palaeogeographic and structural evolution to the Ionian realm (Alvarez 1989, Karakitsios 1995). All the correlations can be seen in Figure 4.

The lower part of the Gotzikas section, comprising the Vigla Shale Member, records rhythmic alternations of organic carbon rich/poor horizons, which can be correlated with the Selli event (OAE1a). In the lowermost $4.5 \mathrm{~m}$, cherty/marly limestones alternate with black shale horizons. This is probably an equivalent of the Fourcade siliceous level described by Danelian et al. (2004) (Fig.4). However deposition appears to have taken place in a different palaeogeographical setting, allowing for the deposition of carbonate as well as siliceous sediments. This is in agreement with previous studies conducted in this area, which provide evidence for intense sea bottom topography within the Ionian Basin well beyond the syn-rift period, due to the continuation of halokinesis (Karakitsios 1995). It is very probable that carbonate/black shale deposition took place in shallower parts of the basin (e.g. Gotzikas section, especially the upper Lower Aptian part), and chert/black shale deposition in the deeper parts of the Ionian Basin (e.g. Paliambela section).

A single black shale horizon of Early Albian age, $\sim 15 \mathrm{~m}$ below the Paquier level (OAElb), can be correlated with Mt. Nerone level described in the Umbria - Marche region. The OAE1b level is correlated with the Urbino level described in the same sequence (Galeotti et al. 2003).

The sediments immediately above the Paquier level (22-33 m; Fig. 4) are most likely to be equivalent to the Dercourt member, described by Danelian et al. (2004) in the Paliambela section. The lithology of this part of the section is comprised of limestone and chert interbeds and cherty limestones. Within this unit three black shale horizons have been observed. Whereas field observation of the Paliambela section show shale and siliceous mudstones alternating with cherty layers. The biostratigraphic age of this portion of the Vigla Formation is Middle Albian in both cases.

The upper three black shale horizons, below the Bonarelli level, can be correlated with the OAElc, which, according to Bralower et al. (1993), spans the entire planktic foraminiferal Biticinella breggiensis Zone. This event includes the Amadeus Segment described in detail by Galeotti et al. (2003), during which black shale deposition appears to be orbitally controlled.

\subsection{Cyclostratigraphy}

A cyclostratigraphic methodology was applied to the Lower Aptian Vigla Shale Member deposits (lowermost $13.22 \mathrm{~m}$ of the section), using field observations and bulk $\delta^{13} \mathrm{C}$ data (Table 2). In order to identify periodic patterns in the isotopic content of the deposits, spectral analysis on the $\delta^{13} \mathrm{C}$ time-series was applied, using AnalySeries (Paillard et al. 1996; Figs 5-7).

Processing of the data, prior to spectral analysis, involved detrending (incorporating mean subtraction), pre-whitening (coeff. $=0.7$ ), and arc sine transformation (Weedon 2003). Linear interpolation was also necessary, since the section was not equally sampled. Following this, a check for stationarity (i.e. a time-series' property of changing its characteristics significantly over the length of the studied interval; Weedon 2003) was conducted by comparing the spectra of several overlapping segments of the dataset.

The spectral analysis employed three different methods; the maximum entropy method (Percival and Walden 1993), the multi-taper method (Thompson 1982), and the Blackman - Tukey method (Priestley 1981) (Figs 5-7). The maximum entropy method (MEM) with a Burg algorithm assumes the presence of multiple autoregressive processes (AR processes). An AR process involves a dependence of each successive value in the dataset, on previous values (Weedon 2003). However, this is probably true for Mid-Cretaceous sediments recording oceanic anoxic events. The processes that seem to trigger and control these events (gas-hydrate release, primary productivity increase, or high detrital input) are evolutionary through geological time. Thus the parameters that record the phenomena (e.g. $\delta^{13} \mathrm{C}, \delta^{18} \mathrm{O}$ ) can indeed be thought to incorporate a "memory" of sorts, which in essence defines AR processes. As a result the MEM could be considered a valid method of 


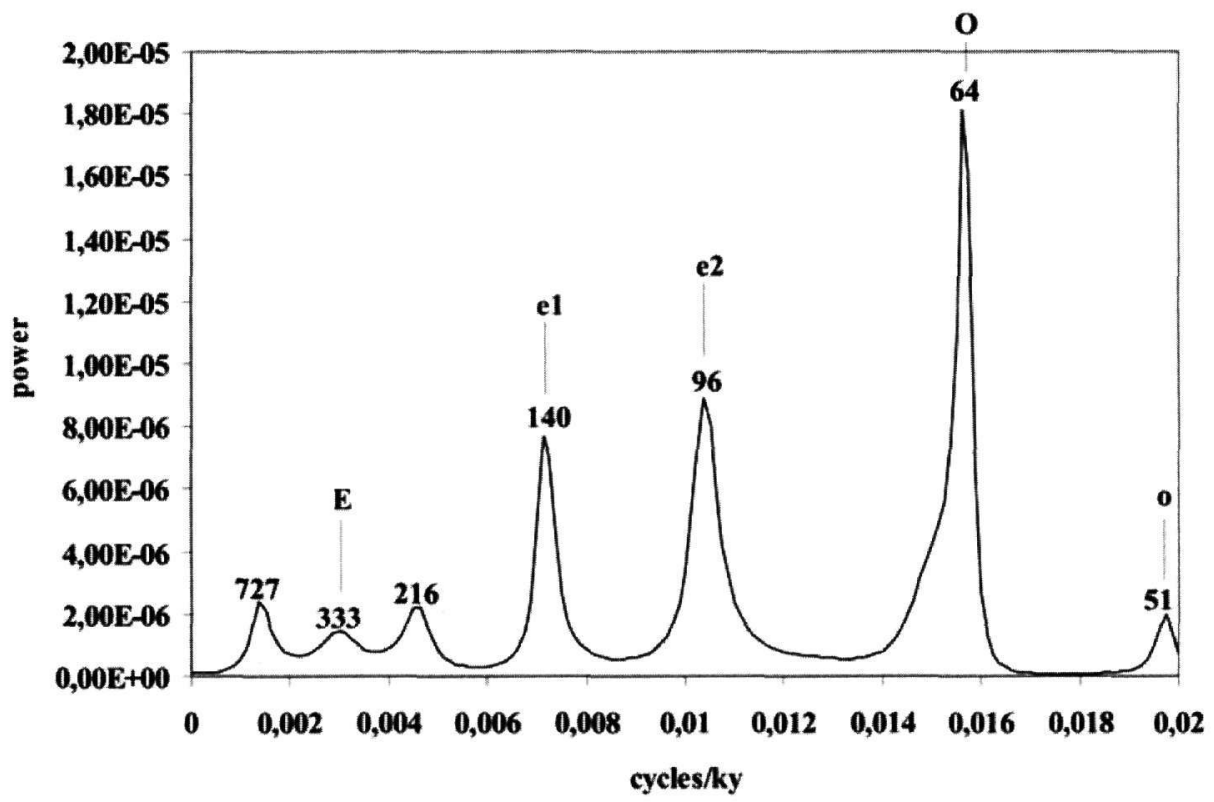

Figure 5 - Power spectrum $\left(\delta^{13} \mathrm{C}\right.$ time-series) for the lower part of the section, produced through the maximum entropy method (MEM), with a length of filter equal to 28 (relatively

good resolution and confidence levels). Numbers on the peaks indicate the period

(1/frequency). E: long eccentricity rhythm ( $\sim 404.1 \mathrm{ky}$ distorted $)$, e1: short eccentricity rhythm mode 1 ( 123.9 ky according to Laskar, 1999), e2: short eccentricity rhythm mode 2

( $\sim 94.8 \mathrm{ky}$, also by Laskar, 1999), O: obliquity rhythm amplitude modulation of a $\sim 62.5 \mathrm{ky}$ period (Grippo et al. 2004), and o: secondary obliquity cycles of $\sim 54 \mathrm{ky}$ periodicity (Grippo et al. 2004)

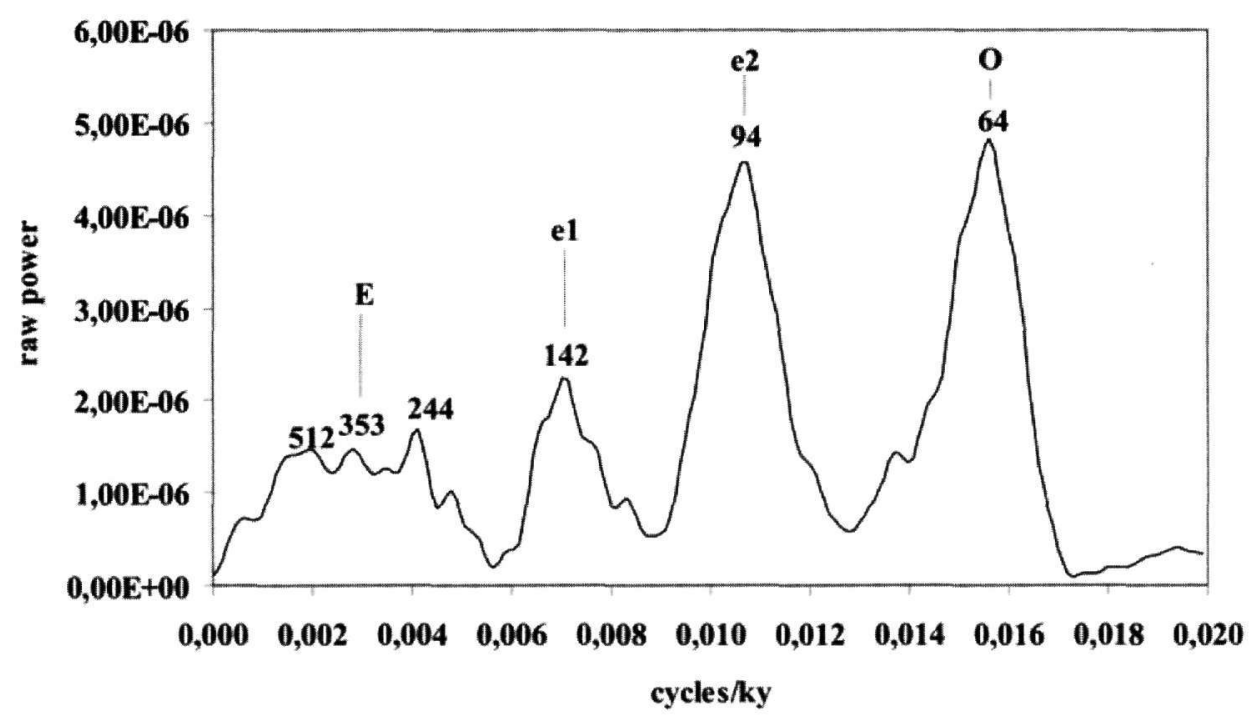

Figure 6 - Power spectrum $\left(\delta^{13} \mathrm{C}\right.$ time-series) for the lower part of the section, produced through the multi-taper method (MTM). The number of tapers was chosen at 3, in order to achieve higher confidence levels. Numbers on the peaks indicate the period ( 1 /frequency) 
spectral estimation for this type of cyclostratigraphic data. In order to avoid the slight shift of the frequency, that often occurs with this method, the actual valid peak frequencies were here determined by the use of the multi-taper method (MTM) and the Blackman - Tuckey method (BTM). These two methodologies are non-parametric, and therefore they do not involve any assumptions about the nature of the dataset (Weedon 2003). Also the spectra produced by each different method have a different $y$-axis scale. Normalization was not considered important since in cyclostratigraphic studies, the form of the spectra is significant and not the power.

Examination of the power spectra produced by all three methods has enabled an estimation of the regular cycles recorded in the sedimentary record, observed in Gotzikas section. The long eccentricity signal $(\mathrm{E})$ is somewhat distorted and exhibits non-linear higher frequency combination tones, probably due to the control of long eccentricity over the sedimentation rate (Weedon 2003). However, the long eccentricity rhythm modulation appears consistently through all three spectra. In addition amplitude modulation cycles of $727 \mathrm{ky}$ period, which appear in both the MEM and the BTM spectra, and $353 \mathrm{ky}$ period, in the MTM spectrum, probably result from the added effect of the precession and eccentricity periodicities (Grippo et al. 2004).

As exhibited consistently by all three spectral estimation methods, the black shale deposition during the Lower Aptian interval in the Ionian Basin was strongly controlled by the short eccentricity signal of $\sim 123.9 \mathrm{ky}$ (e1) and $\sim 94.8 \mathrm{ky}$ (e2) (periodicities follow the calculations of Laskar, 1999 for the last $19 \mathrm{My}$ ). This e1 mode results from the interactions between the systems of Jupiter, Mars and Jupiter, Earth., whilst the e 2 mode is controlled by the Mars, Venus and Earth, Venus systems (Laskar 1999).

The "precession of the equinoxes", which derives from the wobble of the Earth's rotational axis, has an influence on climate depending on its interaction with the ellipticity of the Earth's orbit (essentially eccentricity). Earth and Mars' gravitational attraction forms the precessional periodicity at $19 \mathrm{ky}$ which, combined with the mode of $23 \mathrm{ky}$ formed by the Jupiter and Mercury gravitational fields, provides the precessional cyclicity at $21 \mathrm{ky}$.

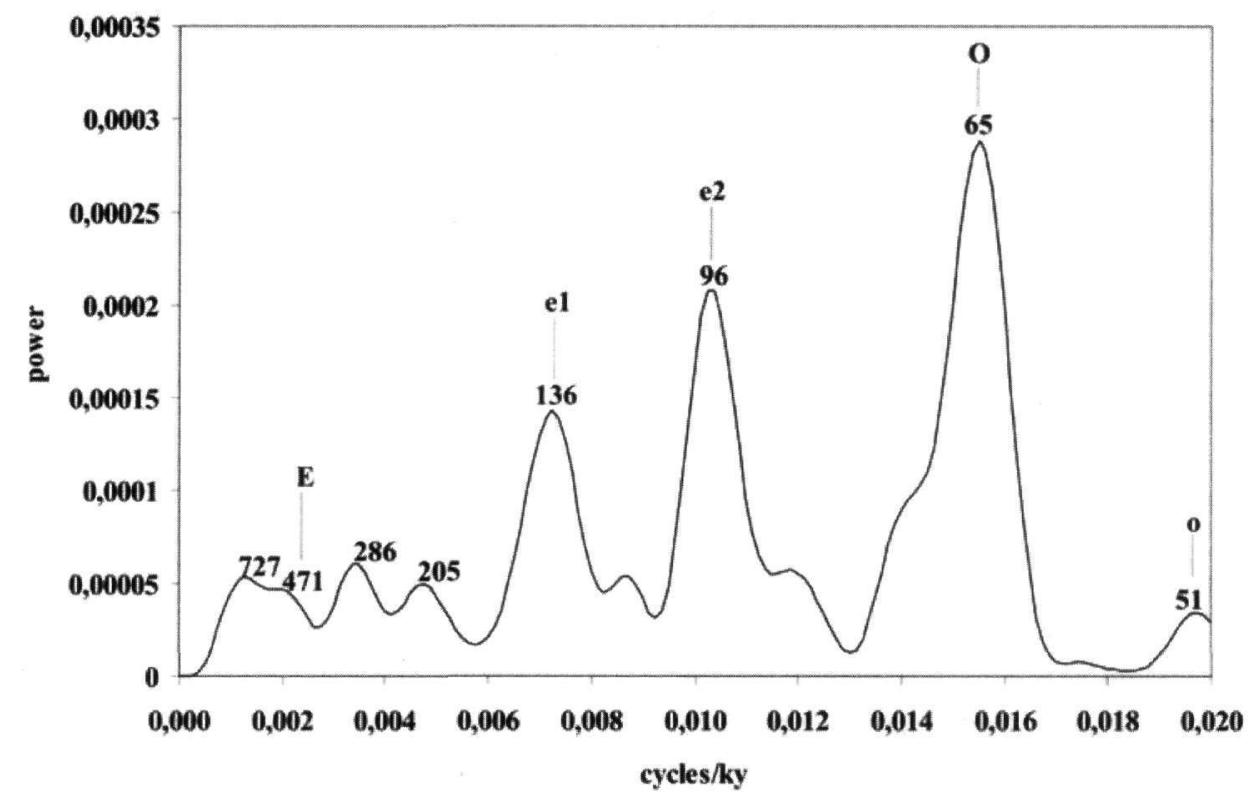

Figure 7 - Power spectrum $\left(\delta^{13} \mathrm{C}\right.$ time-series) for the lower part of the section, produced through Blackman - Tukey method (BTM), with $80 \%$ confidence interval. Numbers on the peaks indicate the period (1/frequency). Number of lags $=\mathbf{5 0}$ 
Earth's interactions with Mercury, Venus, Mars and Jupiter also affect the axial inclination, because of the pull exerted on the Earth's equatorial bulge (Laskar, 1999). This effect results in the obliquity cycles, the main period of which is $41 \mathrm{ky}$. Saturn additionally induces a lesser cycle at 54 ky. Because these periodicities of the orbital rhythm are closely spaced, they produce several amplitude modulations. The size of the sampling interval in the lower part of Gotzikas section did not allow for observation of the high frequency components of obliquity in the spectra produced. However we can observe the 54 ky-period mode in the MEM and the MTM spectra. According to Grippo et al. (2004), this peak may be suppressed (as in our case), when observed in low and mid latitudes, because its presence in these records is strongly dependent on the degree of degradation of this signal during transmission (since it is originally generated in the polar region). In all three spectra the $62.5 \mathrm{ky}$-period amplitude modulation mode of obliquity can be clearly observed. Note that Laskar (1999) estimates that the Earth's obliquity variation, the most unstable of the orbital parameters, is not expected to have remained stable over longer geological times. Nevertheless, consistency in our spectral analysis suggests an indirect estimate of obliquity regular cycles' control on sedimentation, in the lower part of Gotzikas section.

Slight shifts in the periodicities of the orbital cycles, as shown in the spectra (Figs 5-7), relative to those predicted by Laskar (1999), are observed and may be explained in a number of ways. These power spectra are based on a hypothesized age model (assuming constant sedimentation rates), formulated according to the biostratigraphic and field data, and in conjunction with the regional correlation presented. Therefore the expected discrepancies between the above age model and the actual age-depth relationship would tend to shift the regular cyclicity frequencies in the spectra. Furthermore, the calculations of the orbital parameters produced by Laskar (1999) range back to the last 19 My only. It is highly improbable that the same parameters stand true for MidCretaceous time as well. Finally, general limitations of the pre-processing and spectral estimation methods applied herein may have contributed to the shifts in spectral frequencies.

\section{Discussion}

Orbital eccentricity is responsible for changes in Earth's insolation, especially expressed in seasonality. In general higher eccentricity intensifies the seasons in the hemisphere in which the perihelion occurs during the summer, and the amplitude of these climatic deviations is proportional to the amount of eccentricity. The four eccentricity rhythms, introduced by the gravitational interactions between the planets, in conjunction with the precessional cycles, have a combined effect on climate. This is maximized at the frequencies corresponding to the "difference tone" or the "combination tone" between them (Laskar 1999).

The precession - eccentricity syndrome is thought to be responsible for a decrease in deep-water oxygenation, dysoxia intensifying, at certain times, to the point of anoxia. At these periods, dark marly beds, with elevated organic content and iron sulfide, have been widely deposited (Herbert $e t$ al. 1986b, Galeotti et al. 2003, Grippo et al. 2004). These thin precessional anoxic pulsations (PAPs) segment the stratal sequence, into organic-carbon rich and organic-carbon poor horizons. It is proposed here that the lithological alternations observed in the Lower Aptian part of Gotzikas section are caused by such precessional anoxic pulsations, modulated by the precession eccentricity syndrome.

Comparison between the orbital cyclicities and amplitude modulations calculated by Laskar (1999), and the age model hypothesized for this part of Gotzikas section, allows the conclusion that, when moving backwards within this Lower Aptian segment, the deposition of the black shale horizons was modulated by longer-period precessional amplitude modulations. It can be observed that the duration of time (according to the age model) between consecutive black marls and shales (PAPs) generally increased from $\sim 14-15 \mathrm{ky}$ to $\sim 53 \mathrm{ky}$ through the lowermost part of the section. This phenomenon may be due to an actual change of the modulation mechanism. However, as sedimentation of the lowermost part of the section (equivalent to the Fourcade level of Danelian et 
al., 2004) took place in a deeper, more siliceous environment, black shale deposition may have been controlled by lower frequency orbital periodicity.

According to Herbert et al. (1986a, 1986b), like the precession - eccentricity syndrome, obliquity cycles drove variations in carbonate production and bottom redox conditions. Grippo et al. (2004) report thicker and more abundant PAPs and relatively pure limestones in the Piobbico core (Scisti e Fucoidi Fm - Scaglia Bianca sequence, Umbria Marche, Italy) coinciding with strong obliquity signals. According to these authors this observation suggests that primary productivity increased during these times.

There are two main theories regarding the mechanisms triggering black shale formation and PAPs. According to de Boer (1983) carbonate production is a function of primary productivity, meaning that episodes of exceptional organic carbon preservation triggered black shale deposition. On the other hand, Herbert et al. (1986a) provided evidence to support increased primary productivity in the carbonate-rich phase, thus suggesting organic hyperproduction as the mechanism responsible for PAPs. Grippo et al. (2004) reason that the biotic record favors de Boer's model, and thus assign the PAPs in the Scisti e Fucoidi Formation to the perihelial winter phase of the precessional cycle of low seasonality. Similarly, Galeotti et al. (2003) proposed a model for black shale deposition during the Upper Albian, in the Umbria - Marche region. According to these authors, black shale sedimentation occurred during precession minima, in times of increased precipitation, enhanced continental runoff and stratification of the upper water column.

Regarding the Lower Aptian interval in the Ionian Zone, Danelian et al. (2004) indicate that the highly siliceous Fourcade level of Paliambela section constitutes a local record of a global ocean eutrophication event during the OAEla (Baudin et al. 1998, Hochuli et al. 1999). This is in agreement with observations for the same interval of Gotzikas section. We therefore propose that the Lower Aptian portion of this section (lowermost $13.22 \mathrm{~m}$ ) is equivalent to the OAE1a event, and the lowermost more siliceous part of these sediments, to the Fourcade level of Paliambela section. Orbital forcing in conjunction with increased upwelling due to the opening of new Mediterranean Tethys gateways, as suggested by Danelian et al. $(2002,2004)$, may have indeed been the cause of the high productivity episode recorded as the OAE1a event in this region.

\section{Acknowledgements}

This project is co-funded by the European Social Fund and National Resources (EPEAEK II) PYTHAGORAS II (70/3/7950). The authors would also like to thank Professors Dr. A.G. Fishcer and Dr. M. Sprovieri for kindly reviewing the manuscript.

\section{References}

Alvarez, W., 1989. Evolution of the Monte Nerone seamount in the Umbria-Marche Appenines: 2. Tectonic control of the seamount-basin transition, Boll. Soc. Geol. Ital., 108, 23-39.

Baudin, F., Fiet, N., Coccioni, R., and Galeotti, S., 1998. Organic matter characterization of the Selli Level (Umbria - Marche basin, central Italy), Cretaceous research, 151, 701-714.

de Boer, P.L., 1983. Aspects of Middle Cretaceous pelagic sedimentation in southern Europe: production and storage of organic matter, stable isotopes and astronomic influences, Geologica Ultraiectina, 31, 112p.

Bralower, T.J., Leckie, R.M., Sliter, W.V., and Thierstein, H.R., 1995. An intergrated Cretaceous microfossil biostratigraphy, In W.A. Berggren, D.V. Kent, M.-P. Aubry and J. Hardenbal (eds), Geochronology, Time Scales, and Global Stratigraphic Correlation, SEPM Sp. Publ. $54 p$. 
Bralower, T.J., Sliter, W.V., Arthur, M.A., Leckie, R.M., Allard, D., and Schlanger, S.O., 1993. Dysoxic/anoxic episodes in the Aptian-Albian (Early Cretaceous). In M. Pringle, W.W. Sager, W.V. Sliter and S. Stein, (eds), The Mesozoic Pacific: Geology, Tectonics, and Volcanism, AGU Monograph 7, 5-37pp.

Danelian, T., Baudin, F., Gardin, S., Beltran, C., and Masure, E., 2002. Early Aptian productivity increase as recorded in the Fourcade level of the Ionian zone of Greece, C.R.Geoscience, 334, 1087-1093.

Danelian, T., Tsikos, H., Gardin, S., Baudin, F., Bellier, J.P., and Emmanuel, L., 2004. Global and regional palaeoceanographic changes as recorded in the mid-Cretaceous (Aptian - Albian) sequence of the Ionian Zone (NW Greece), J. Geol. Soc. London, 161, 703-710.

Erbacher, J. Thurow, J., and Little, R., 1996. Evolution patterns of radiolaria and organic matter variation: A new approach to identify sea-level changes in mid-Cretaceous pelagic environments, Geology, 24, 499-502.

Galeotti, S., Sprovieri, M., Coccioni, R., Bellanca, A., and Neri, R., 2003. Orbitally modulated black shale deposition in the Upper Albian Amadeus Segment (central Italy): a multi-proxy reconstruction, Palaeo, Palaeo, Palaeo, 190, 441-458.

Gradstein, F.M., Ogg, J.G., Smith, A.G., et al., 2004. A Geologic Time Scale 2004, Cambridge University Press.

Grippo, A., Fischer, A.G., Hinnov, L.A., Herbert, T.M., and Premoli Silva, I., 2004. Cyclostratigraphy and chronology of the Albian stage (Piobbico Core, Italy), Cyclostratigraphy: approaches and case histories, SEPM Sp. Publ. 81, 57-81.

Herbert, T.D., and Fischer, A.G., 1986a. Milankovitch climatic origin of mid-Cretaceous black shale rhythms in central Italy, Nature, 321, 735-743.

Herbert, T.D., Stallard, R.F., and Fischer, A.G., 1986b. Anoxic events, productivity rhythms and the orbital signature in a mid-Cretaceous deep-sea sequence from Central Italy, Paleoceanography, 1, 495-506.

Hochuli, P.A., Menegatti, A.P., Weissert, H., Riva, A., Erba, E., and Premoli Silva, I., 1999. Episodes of high productivity and cooling in the early Aptian Alpine Tethys, Geology, 27, 657-660.

Jenkyns, H.C., 1980. Cretaceous anoxic events: from continents to oceans, J. Geol. Soc. London, $137,171-188$.

Karakitsios, V., 1992. Ouverture et inversion tectonique du bassin ionien (Epire, Grece), Ann.Geol.Pays Hell., 35, 85-318.

Karakitsios, V., 1995. The influence of pre-existing structure and halokinesis on organic matter preservation and thrust system evolution in the Ionian Basin, Northwestern Greece, $A A P G$ Bull., 79, 960-980.

Karakitsios, V., Tsikos, H., van Breugel, Y., Koletti, L., Sinninghe Damste, J.S., and Jenkyns, H.C., 2007. First evidence for the Cenomanian - Turonian oceanic anoxic event (OAE2, "Bonarelli" event) from the Ionian Zone, western continental Greece, Int. J. Earth Sci (Geol. Rundsch.), 96. 343-352.

Laskar, J., 1999. The limits of Earth orbital calculations for geological time-scale use, Royal Soc. (London), Phil. Trans., series A, 357, 1735-1759.

Paillard, D., Labeyrie, L., and Yiou, P., 1996. Macintosh program performs time-series analysis, EOS Transactions AGU, 77, 379. 
Parrish, J.T., 1995. Paleogeography of $\mathrm{C}_{\text {org }}$-rich rocks and the preservation versus production controversy. In A.Y. Huc (ed.), Paleogeography, paleoclimate and source rocks, AAPG studies in geology 40, 1-20.

Percival, D.B., and Walden, A.T., 1993. Spectral Analysis for Physical Applications. Multitaper and Conventional Univariate Techniques, Cambridge University Press, Cambridge, 583pp.

Premoli Silva, I, and Sliter, W.V., 1995. Cretaceous planktonic foraminiferal biostratigraphy and evolutionary trends from the Bottaccione section, Gubbio, Italy, Palaeontogr. Ital., 82, 189.

Priestley, M.B., 1981. Spectral Analysis and Time Series, Academic Press, London, 890pp.

Rigakis, N., and Karakitsios, V., 1998. The source rock horizons of the Ionian Basin (NW Greece), Mar. Petrol. Geology, 15, 593-617.

Thompson, D.J., 1982. Spectrum estimation and harmonic analysis. Proc. IEEE, 70, 1055-1096.

Tsikos, H., Jenkyns, H.C., Walsworth-Bell, B., Petrizzo, M.R., Forster, A., Kolonic, S., Erba, E., Premoli Silva, I., Baas, M., Wagner, T., and Sinninghe Damste, J.S., 2004a. Carbon isotope stratigraphy recorded by the Cenomanian - Turonian oceanic anoxic event: correlation and implications based on three key localities, J. Geol. Soc. London, 161, 711720 .

Tsikos, H., Karakitsios, V., van Breugel, Y., Walsworth-Bell, B., Bombardiere, L., Petrizzo, M.R., Sinninghe Damste, J.S., Schouten, S., Erba, E., Premoli Silva, I., Farrimond, P., Tyson, R.V., and Jenkyns, H.C., 2004b. Organic-carbon deposition in the Cretaceous of the Ionian Basin, NW Greece: the Paquier event (OAE1b) revisited, Geol. Mag., 141, 401-416.

Tyson, R.V., 1995. Sedimentary organic matter: organic facies and palynofacies, Chapman and Hall, London, 615 p.

Weedon, G.P., 2003. Time-series analysis and Cyclostratigraphy, Cambridge University Press, $259 \mathrm{pp}$. 